\title{
FOOD PRICE VOLATILITY EFFECT OF EXCHANGE RATE VOLATILITY IN NIGERIA
}

\section{Edamisan Ikuemonisan, Igbekele Ajibefun, Taiwo Ejiola Mafimisebi}

(1)Department of Agricultural Economics, Faculty of Agriculture, Adekunle Ajasin University, Akungba Akoko, Ondo State, Nigeria

(2) Department of Agricultural Economics, Faculty of Agriculture, Adekunle Ajasin University, Akungba Akoko, Ondo State, Nigeria

(3) Department of Agricultural and Resource Economics, School of Agricultural and Agricultural Technology, The Federal University of Technology Akure

Edamisan Ikuemonisan

Department of Agricultural Economics, Faculty of Agriculture, Adekunle Ajasin University, Akungba Akoko, Ondo State, Nigeria edamisan.ikuemonisan@aaua.edu.ng

Article info

Paper category: Preliminary Paper Received: 15.3 .2018 .

Accepted: 8.1.2019.

JEl classification: $\mathrm{C}_{5}, \mathrm{I} 3, \mathrm{R}_{2}$ DOI: $10.32728 /$ ric. $2018.44 / 2$

Keywords

Food Price Volatility; Exchange Rate Volatility; Leverage Effect; Persistence; Spillover; EGARCH Model 


\begin{abstract}
Purpose. There are sufficient evidences in the literature that welfare of food producers and consumers is easily compromised due to unfavorable food price volatility dynamics. Therefore, this study investigates the volatility dynamics in food price index returns (FPIRETURNS), imported food price index returns (CIFCPIRETURNS), price of dollars at bureau de change (BDCRETURNS) and inter-bank rate (EXRETURNS).

Design/Methodology/Approach. In view of the increasing quest to account for volatility behavior such as non-linear and time-varying risk premium in food price series using an appropriate tool, this paper adopts exponential generalized autoregressive conditional heteroscedasticity (EGARCH) model. This is because it allows error terms to be conditional heteroscedastic, and the dynamics process generating the underlying heteroscedasticity to be asymmetric. That is, the model introduces a parameter that can reveal how conditional variance respond to both positive and negative shocks of equal magnitude (asymmetric effect).
\end{abstract}

Findings and Implications. The study finds leverage effect and high persistence in some of the selected models. Also, exchange rate volatility affects volatility of FPIRETURNS, but it is more pronounced on the volatility of CIFCPIRETURNS.

Limitations. Inadequate data especially for CIFCPIRETURNS is a huge limitation in this study.

Originality. However, this study has sufficient empirical evidences that instability in forex market flows into the Nigerian food market with pronounced leverage effect and persistence in food price volatility. The recommendation is, government should implement stabilization policy in the forex market as a precursor to ensuring stability in domestic food market. 


\section{INTRODUCTION}

Many households in low income countries have continued to wallow in poverty because of the perceived weakness and less skills in taking informed decision about their livelihood. The inconsistent pattern in policy implementation creates so much uncertainty in the economy. Food market is one place where signals about the behaviour of market participants are best examined. An average household in Nigeria spends more than $60 \%$ of household income on food (Mgbenka, Mbah, Ezeano, 2015). This is an evidence of the centrality of food in household expenditure. It implies that implementation of household budget can easily be distorted by inefficient and unstable food market dynamics, thereby resulting into changing consumption habit. Similarly, uncertainty in food market has been implicated in the rising food inflation in low income countries (Sehakar, Roy, Bhatt, 2017) and this may create more instability in the economy. Although the literature is replete with findings on predictable price changes (Assefa, Meuwissen, Lasink, 2016), there are evidences that this does not stimulate risk in food market as much as unpredictable changes in food prices. Two problems have emerged in the literature on unpredictable movement (risk) in food prices; evidences of asymmetric effects (leverage effects) in food prices suggest differential price risk (sudden change) depending on direction of price movement, and that persistence in food price volatility stimulates food price inflation and low investment. The fact that Nigerian food economy has been continually troubled by low investment in the agricultural and food sector has heightened our curiosity about the cloudy nature of food market. All these are possible precursor to food insecurity which incontrovertibly have welfare implications on the people especially the low income earners and rural poor who are dominantly peasant farmers (Pinstrup-Andersen, 2015; and Sassi, 2014). Therefore, a deep knowledge of food price volatility dynamics can have both intellectual and policy implications with a view to addressing food insecurity and its attendant challenges in Nigeria and other low income countries.

Experts have asserted that food price volatility (FPV) is a global phenomenon (FAO et al., 2011; IFPRI, 2013 and HLPE, 2011). It is the frequent and unpredictable changes to food prices over a period of time (Assefa, Meuwissen, Lansik, 2015; Serra, Zilberman, 2013; Piot-Lepetit, 2011; FAO et al., 2011; and Rabobank, 2011). These changes can affect a number of market variables directly - demand and supply, price, production, and inventory; and indirectly - welfare of producers, traders and consumers (Pindyck, 2004). The increasing impact of food price volatility on smallholder farmers and other pro poor households in the developing countries is daunting (IMF, OECD, and WFP UNCTAD, 2011; IFPRI, 2013; FAO et al., 2011; and Minot, 2014). It is a well-known fact that smallholder farmers and agribusiness folks are dominant among economic agents in Nigeria economy (Akor, 2012; and Fatuase et al., 2016) and they are predisposed to frequent food price fluctuations. Therefore, 
stability in food economy is one of the key instrument to sustainably keep the welfare of the people in proper economic shape. It is in view of this goal that policy makers and economists have continually paid attention to global food price dynamics. Volatility dynamics in food market is the totality of responses to different types of news including instability in exchange rate (Ogundipe, Ojeaga, Ogundipe, 2013; Chit et al., 2010; Jozsef, 2011, and Nwoko et al., 2016). This response, in a high food importing and developing countries, has various policy implications. It can induce rising food prices (Brinkman, Hendrix, 2011; and Sol, Morales-Opazo, Garrido, Demeke, and Bardaj, 2013), and this is a constraint to access adequate food and nutrition. The effects of this in developing and low income countries include but not limited to increasing food related crises, poverty and poor consumption habit. The state of food economy, to a large extent, dictates the pace of growth in other sectors of any economy. Therefore, failure to achieve stability in food and agricultural commodity prices may; aggravate inefficiencies, cause less competitiveness, increase food prices and also prompt global food insecurity (HLPE, 2011; Gilbert, Morgan, 2010; Hajkowicz, Negra, Barnett, Clark, Harch, Keating, 2012; and Minot, 2013). Although financial experts have opined that one off spikes in price is not abnormal in trading cycle however, posited that high persistence in volatility bears high intensity of risk (Jain, Strobl, 2016) and causes inflation in food prices (Sehkar, Roy, Bhatt, 2017). Therefore, volatility persistence is of interest in analyzing food and agricultural market. Food price volatility affects both food consumers (food expenditure) and producers (food prices - income). In low and middle income countries, household expenditure put serious pressure on household income at the expense of other financial obligations. On the other hand, agriculture provides direct and indirect jobs for over $60 \%$ of Nigerian population (Nigerian Bureau of Statistics). Risk in food market therefore, becomes intolerable when it is persistent. Production and market risks in agriculture and agribusiness have been linked to weather, inadequate access to input and output market, international market dynamics, multiple contracts period spillover etc. In developing countries, policy strategies to mitigate against price volatility have produced both positive and counter-positive effects. For instance, periods of obstructive monetary policy have resulted into frequent changes in value of dollar and most often, this consistently altered food price dynamics known market fundamentals. Oyejide (1986) and Ogundipe, Ojeaga, Ogundipe (2013) robustly discuss the influence of exchange rate policies on agriculture and economy in Nigeria. Therefore, achieving price (market) stability without robust discourse on price dynamics, level price and price volatility, will be difficult.

Price volatility is characterized by both upward and downward spikes in price movement. Besides market endogenous factors, these spikes are partly linked to market response to both government fiscal expansion and contractionary measures respectively. Importers and traders at domestic market often find periods with marked and frequent changes in exchange rate as difficult periods because they are 
usually unable to meet their financial obligations to creditors. It is also a period of heightened risk in the foreign exchange (forex) market. The dynamics in the forex market is largely influenced by the volume of export relative to import. Nigeria is a net exporter and importer of crude oil and fuel respectively, and the volume of what is exported and imported makes her a dominant player in the global oil market. Trading activities in the world oil market remarkably influenced Nigerian currency since 1983 culminating into both favourable and unfavourable trade balances. The consequence is the exposure to dollar denominated debt. On the other hand, Kafle (2011) opines that agricultural production in low income countries is susceptible to the subtleties in forex market. For instance, according to Olusoji et al. (2014), Nigeria spent more than five times of income from food exports on food import bills. This expenditure patterns percolates down to household level. The degree of impact on the rural households depends on the coping strategies by the households, available social safety and stabilization measures by government.

Theoretically, low output induces supply falls and thus, price also goes up. A lot of factors affect domestic production in Nigeria hence, domestic food supply is not only inelastic and low but also not sufficient to meet demand. The risk averse producers are known to be highly cautious to avoid losses due to risk. The exploitation becomes complicated where insurance literacy is still abysmally low and only very few participants are involved. In view of this, food imports augment the inadequate domestic food supply. The forex market has been implicated in the dynamics of both agricultural input and output (food) markets (Ogundipe, Ojeaga, Ogundipe, 2013). Farm and processing machines, fuel, fertilizers and farm chemicals are imported while cash crops like cocoa, rubber and cotton with little of food products are exported. In completing these transactions, the price of dollar at forex market takes centre stage. This is one of the reasons it has become essential to know the degree of dependence of food price volatility on forex market instability. Findings have shown that the consumption behavior of poor households in the low income countries is largely influenced by food price volatility (Sol et al., 2013; Coyle, 1992; Haile et al., 2014; and Bellemare et al., 2013). Besides, high food price spike can also aggravate poverty (HLPE, 2011). For instance, shortly after the 2008 episode of global financial crises, the proportion of people, particularly in the sub-Saharan Africa, living on US\$1.90 or less per day as a result of the pass through effect of price volatility increased to $47 \%$ from the previous $40 \%$ (Wilson, 2015). Even after that episode in 2008, not much is known about food price volatility in Nigeria but in the last two decades, food prices trend in similar order as exchange rate. Many countries' including Nigerian forex market have also witnessed series of instability that contribute largely to general uncertainty in the average economy. There are concerns that this instability affects food prices, food price inflation and ultimately, the welfare of the both food producers and consumers. Experts have suggested the combination of well-grounded financial measures and macroeconomic measures as pre-conditions 
for global economic rebound (Ferrara et al., 2018). Therefore, it is expected that adequate understanding of the food market dynamics can help policy makers on the appropriateness of strategies to reduce uncertainty in the economy with a view to enhancing households' welfare.

According to Newberry (1989), price volatility negatively affects both consumers and producers. Therefore, importance of agriculture and food in Nigeria economy cannot be over-emphasized. Hence, both the food price and its volatility have significant effects on Nigeria economy. This accounts for the close monitoring of the food market by producers, consumers, investors, and policymakers. It has been observed that both the type of news (positive or negative) and the degree of shocks to the variance (permanent or otherwise) have varying effects on food price volatility. Therefore, a very efficient food price volatility model will accommodate the perceptions on these endogenous and other likely exogenous factors in it. However, the challenges confronting forex market in Nigeria are deep and have become the nightmare of importing traders (including importation of food and agricultural input). The major problems confronting the forex market is that of multiplicity and the gap between the official and parallel market rates. The activities of the street hawkers (black market) have been implicated in these problems by players like Nigerian Inter-Bank Market, Bureau De Change (BDC) and Financial Market Dealers Quote (FMDQ). Furthermore, the influence of exchange rate on food market has been well argued hence, forex trading activities of Bureau De Change (BDC) and Inter-bank market (EXR) are spot on. There have been series of argument for and against the position that the frequent changes in the price of dollar affect food price volatility. The forex trading activities of BDC and Inter-bank market help to ensure stability in the forex market by ensuring a convergence between official and parallel market exchange rate. It is not uncommon to hear traders lament when exchange rate spikes very frequently. The Central Bank of Nigeria continually deploys various measures to guarantee stability in forex market. Although few studies have modelled food price volatility in Nigeria, it is critical to point out that most of the authors omitted the influence of the endogenous and exogenous factors on food price volatility. Such omission, which include modelling price volatility without recourse to structural breaks (endogenous) and influence of other markets such as forex market (exogenous) in the return series, can lead to spurious conclusions.

This study attempts to analyze the response of food price volatility to both positive and negative news and the persistence of these shocks with adequate attention paid to structural breaks in the mean equations. In order to achieve these: (1) we investigate the asymmetric volatility response to both positive and negative news; (2) we assess volatility persistence in food price volatility; and (3) we examine the pass through effect of exchange rate (BDG and EXR) volatility on conditional volatility of food prices in Nigeria. The significance of this study is its contribution to the debate on food price dynamics in Nigeria. It increases available information on food price 
movement to major participants in food value chain and also widens the policy options required to manage food price stability.

Other parts of the paper are structured as follows: session two reviews the related literature to the study; session three focuses on theory and methods; discussion on results of model estimation is in session four; and the conclusion is on session five.

\section{LITERATURE}

Globally, empirical studies have been carried out on stock and food price volatility, volatility persistence, asymmetry of distribution error and leverage effects. Persistence to food price volatility is capable of delaying the return of food prices to its mean value. According to Sehkar, Roy and Bhatt (2017), persistence food price volatility predisposes food prices to food price inflation. Poterba and Summer (1986) explains that if the variance equation gives a parameter estimate that indicates high volatility persistence, then it implies that the shocks will decay slowly. A high degree of price volatility persistence in shocks to conditional variance is an indication that the perception about low return will linger for a longer period (McAleer et al., 2007). Interpreting that in another way, it means that higher degree of shocks increases persistence in volatility and this can increase food price inflation. This corroborates the findings of Cornia, Deotti, and Sassi (2012). Fasanya and Adekoya (2017) empirically observe the volatility persistence and leverage effects in the consumer price indices (headline and core) and find that there is strong persistence in inflation volatility for both types. Several studies have confirmed persistence in food price volatility (Ajeet, Sascha, 2017; Ismail, Ihsan, Khan, Jabeen, 2016; Ojogho, Egware, 2015; Osarumwense, Waziri, 2013; Rovinaru, Rovinaru, 2013; Omojimite, Akpokodje 2010). However, the literature is not rich enough on how these dynamics reel out on rural food prices and imported food prices in Nigeria.

A number of studies have been conducted to investigate transmission effects across markets (Nwoko, Aye, Asogwa, 2016; Khiyavi et al., 2012; Rezitis, Stavropoulos, 2011; Rezitis, 2010; and Apergis, Rezitis, 2011). Alom et al. (2011) provides an insight to the spillover effect of oil on food prices while Engle and $\mathrm{Ng}$ (1993) give a clue on how to measure the impact of new information on volatility. Their findings buttress the asymmetric state of the impact curves. That is, there is inverse relationship between new information and volatility. The effect of exchange rate volatility on agricultural trade flow is well established in literature (Chit et al., 2010; and Jozsef, 2011), and policy makers have continually made attempts to mitigate against these subtleties in exchange rate. Vita and Abbott (2004) analyzed the impact of exchange rate volatility on US exports to other countries using the ARDL bounds testing approach to cointegration. Nwoko, Aye, and Asogwa (2016) find that oil market volatility is transmitted to food price volatility using Johansen cointegration. A modified two-stage procedure based on modified GARCH in mean has also been used to ana- 
lyze volatility spillover between markets. Ezzati (2013) applied this approach to analyze the international transmission of financial volatility among six countries - US, Germany, Kuwait, Saudi Arabia, Japan and Iran.

Sun, Kim, Koo, Cho and Jin (2002) opine that exchange rate risk has significant and negative effect on wheat export worldwide. Ogundipe, Ojeaga and Ogundipe (2013) found long run relationship between exchange rate and trade balance in Nigeria. However, their findings reveal that money supply volatility, more than exchange rate volatility, affects variances in trade balance. Ott (2010) finds out that uncertainty in exchange rate influences agricultural commodity prices. Similarly, Mushtaq et al., (2011), Yu, Bessler and Fuller (2006); Campiche et al., (2007); Frank and Garcia (2010) have joined the growing list of authors who have provided empirical evidences to support that exchange rate has significant impact on food and agricultural commodity prices. According to the study of Vita and Abbott (2004), their findings reveal that the considered markets are significantly affected by exchange rate volatility. Similar studies also reveal that soybean trade flow is significantly influenced by uncertainty in foreign exchange market (Anderson and Garcia, 1989). Zheng, Kinnucan and Thompson (2008) assert that low (food) prices induce increase in price volatility. Ismail, Ihsan, Khan and Jabeen, (2016) finds inverse relationship between exchange rate and returns. It has been affirmed that frequent changes in exchange rate affect agribusiness, but despite depending on food imports to meet her food demand, the debate on the effect of exchange rate volatility on food price (movement) volatility remains inconclusive. In Nigeria, this narrows down the policy options available for policy makers. In literature, only very few studies have investigated the influence exogenous factors on food price volatility. Besides, it is even rarer to find studies on food price volatility that accommodate structural breakpoints in model estimation. Evidences abound that modelling price volatility without adequate considerations to breakpoint in the series will undermine the prediction power of the model (Salisu, Fasanya, 2013; Salisu, Oloko 2015; and Fasanya, Adekoya 2017).

\section{THEORYAND METHODS}

The first challenge associated with measuring price volatility is how to separate predictable price changes from unpredictable price changes. The literature is replete with evidences that authors measured price volatility using standard deviations and/ or coefficient of variance (Kenyon, 2001; Gilbert, Morgan, 2010; Maurice, Davis, 2011; Minot, 2013; Syampaku, Mafimisebi, 2014; Bobola et al., 2015; and Agunbiade, et al., 2015). The missing gap in the above is that past price and volatility realizations do not have role to play in the determination of the present and future price realizations. This assumption punctures the thought that farmers and other agents in food market understand and can differentiate price processes influenced by seasonal changes and ex-ante knowledge of conditional distribution of prices. This results 
to the striking difference between predictable and unpredictable price changes respectively. Scholars have argued that measuring price volatility without differentiating these two features hypes the degree of risk in price process (Dehn, 2000; and Gilbert, Morgan, 2010).

In order to separate the unpredictable price changes from the predictable price changes, quite a number of authors have provided clues (Ramey, Ramey, 1995; and Moledina et al., 2004). Brown, Halow and Tinic [BHT], (1988) develop Uncertain Information Hypothesis [UIH] to describe the behavior of traders and producers in an unpredictable scenario. The high point of UIH is that flow of unpredictable information (uncertain) or surprises influences market instability, a deviation from market efficiency. Therefore, market's response to uncertain information creates some overreactions. These market reactions, over a period, create a tranquil and spiky phenomenon (Mandelbrot, 1963). It means that a period of tranquility of small returns is intermingled within the period of volatility of large returns. The spikes are evidence of risk a threat to market stability (Prakash, 2011; and Rydberg, Shephard, 2003). Although this theory establishes the influence of uncertain information in market instability but the full impact of the information is not appropriately defined.

Engle (1982) develops an Autoregressive Conditional Heteroscedasticity (ARCH) model to help in modelling price volatility and determine the magnitude of shocks caused by its own shock and independent variables included in the model. It simply captures an autoregressive moving average process for the variance process of time series to give an estimate of the conditional variance of the process per time in the sample. The ARCH model became popular because of how it characterizes changing variance (volatility). ARCH model exposes the relationship that can exist between conditional variance of residuals and the addition of all the squared residuals in the recent past, and because many parameters are required, large lag length is also required (Rydberg, Shephard, 2003). In order to achieve this, the variance of the dependent variable is modeled as a function of past values of the dependent variable and independent or exogenous variables (Green, 2007).

Evidences abound that some financial time series have inbuilt unpredictable features referred to as stylized property (Cont R, 2000) and exhibition of non-constant variance (heteroscedasticity) is also a common phenomenon (Tsay, 2005). All these make some financial time series to defy the normal distribution assumptions hence, the past volatility cannot be used to predict the present of future volatility using the assumptions of Ordinary Least Square (OLS) procedure. Recent studies have shown that food prices, like financial time series, exhibit these stylized and volatile properties (Osarumwense, Waziri, 2013; Ojogho, Egware, 2015; and Ikuemonisan, 2017).

The ARCH model became popular because of how it characterizes changing variance (volatility). GARCH model is relatively better than the ARCH model in terms of parsimony. It also captures the persistence of volatility, though it has its short- 
coming. These include: its inability to capture the symmetric effect of how volatility evolves in response to positive and negative news (leverage effect); the restrictions of non-negativity imposed on the parameter to the estimated, and clumsiness in revealing persistence in stationary series. In view of these challenges, other variants of GARCH model specifically designed to include asymmetric and leverage effects of estimated parameters, the following models have evolved: TGARCH, PGARCH, GJR and EGARCH developed by Nelson (1991). The latter has reliably proved that it can address some of the challenges confronting GARCH model particularly non-negative restriction. This is achieved with logarithmic transformation in the model specification. Similarly, it also expresses leverage effect in the model as exponential. The model introduces a parameter that can reveal how conditional variance respond to both positive and negative shocks of equal magnitude (asymmetric effect). Besides, the appropriate methodological approach to estimate volatility and volatility spillover across markets is also one of the contemporary issues along this conversation.

Therefore, attempt to reject the null hypothesis for no evidence of persistence in food price volatility portends predisposition to food price inflation which can compel low income households to negatively change their feeding habit. For the purpose of policy also, ascertaining the type of news (positive and negative news) that causes volatility persistence in food prices will in the management of the markets/ direction where such innovations/news emanate from. The theory of leverage effect suggests that negative news hypes price volatility. Negative news is usually part of the outcomes of policies that are not well though-out. Above all, frequent changes in policies are hallmark of government in developing countries and these often result in structural breaks in price series. Therefore, evidences of structural breaks can add to the debate on food price volatility.

\subsection{Data and Methodology}

Food is central to household economy in low income countries. According to National Bureau of Statistics (2014), more than zo percent of Nigerians live directly and indirectly on agriculture. Similarly, studies have revealed that more than 60 percent of household income is spent on food (Mgbenka, Mbah, Ezeano, 2015). It may be convenient to state that the market (supply and demand) dynamics affect the predominant rural poor farmers in low income countries as food producers and consumers. According to Olusoji et al. (2014), the evidence that domestic food supply is grossly inadequate hence the need to augment with food importation is the increasing food import bill which is fast depleting forex reserve. The importation dimension to food supply increases the possible influence of forex market. It is in view of these this study considers food prices (on the composite food prices) and forex market (Bureau De Change - BDC and Inter-bank exchange rate-EXR). Data were obtained on food price index (FPI), composite imported food consumer 
price index - CIFCPI, price of dollar in Bureau De Change (BDC) and price of dollar in Inter-Bank Market (EXR) from Food and Agriculture Organization (FAO), National Bureau of Statistics (NBS) and Central Bank of Nigeria (CBN). FPI is aggregated from the retail prices of both domestic and imported food. CIFCPI is aggregated exclusively from retail prices of imported food. BDC and EXR represent the exchange rate at the Bureau De Change and Inter-Bank Market respectively. 320 and 272 observations of price of dollar (BDC) and EXR respectively were obtained from CBN while 86 and 336 observations of CIFCPI and FPI were obtained from National Bureau of Statistics (NBS) and Food and Agriculture Organization (FAO) respectively. In this study, we disaggregated the series: on the basis of start date of observation (block $1-\leq 1995$ and block $2>2008$ ); and on the basis of discarding/ including structural break date in the data series.

Inadequate data was a huge constraint in this study. Since only 86 data points $(2009 \mathrm{M} 11-2016 \mathrm{M} 12)$ of price volatility of CIFCPI returns (CIFCPIRETURNS) were available, we modelled same sample size for FPI returns (FPIRETURNS) with a view to comparing the volatility persistence in each of the disaggregated series (with or without structural breakpoint included in the Mean Equation) and the influence of exchange rate volatility on it. In all, the returns series are formed into sub-samples which are coded as: $R_{1}, R_{2}, R_{3}, \ldots, R_{1} 6$. The disaggregation was done for the purpose of convenience to achieve the objectives of the study. The missing values in the price of dollar at inter-bank market (EXRETURNS) were forecasted using GARCH $(1,1)$. The report is not included in this study because of space.

\subsection{Model Specification}

\subsubsection{Leverage Effect and Persistence in volatility}

Considering the stylized facts attributes of each of the series, we proceed to model the sub-sampled returns series as follows:

We specified $\mathrm{k}$ - variable regression thus:

$Y_{t}=\alpha_{0}+\alpha_{2} X_{2}+\cdots+\alpha_{k} X_{k t}+\varepsilon_{t}$, and $\varepsilon_{t}$ follows a normal distribution hence, it is written as $\varepsilon_{t}=v_{t} \sqrt{h_{t}} \cdot v_{t}$ is a white noise such that $v_{t \sim} N(0,1)$ given that $v_{t}$ and $h_{t}$ follow i.i.d hence, $v_{t} N(0,1)$. It should be noted that $h_{t}$ is an element of an information $\left(F_{t-1}\right)$ set over the previous period of time. It implies that $E\left(\varepsilon_{t} \mid F_{t-1},\right)=\left(v_{t} \sqrt{h_{t}} \mid F_{t-1},\right)=E\left(v_{t} \mid F_{t-1},\right) E\left(\sqrt{h_{t}} \mid F_{t-1},\right)=0 \sqrt{h_{t}}=0$ and $\operatorname{Var}\left(\varepsilon_{t} \mid F_{t-1},\right)=E\left(u_{t}^{2} \mid F_{t-1},\right)=E\left(v_{t} \sqrt{h_{t}} \mid F_{t-1},\right)^{2}=E\left(v_{t}^{2} \mid F_{t-1},\right) E\left(h_{t} \mid F_{t-1},\right)=h_{t}=0$. This is particularly so because $E\left(v_{t}^{2} \mid F_{t-1},\right)=1$ and $\varepsilon_{t \sim} N\left(0, h_{t}\right)$ and $\varepsilon_{t \sim} N\left(0, h_{t}\right)$.

Bollerslev (1986) incorporated lagged terms of the conditional variance $\left(h_{t}\right)$ in the ARCH model to generate infinite order of ARCH model called generalized ARCH (GARCH). At this juncture, we prefer to replace the conditional variance $\left(h_{t}\right)$ with $\left(\sigma_{t}^{2}\right)$. Therefore, GARCH $(1,1)$ can be written as: 
$\sigma_{i t}^{2}=\alpha_{0}+\alpha_{1} \varepsilon_{i t-1}^{2}+\beta_{1} \sigma_{i t-1 .}^{2}$. On the strength that Exponential GARCH (EGARCH) models have taken care of shortcomings GARCH model because it achieves covariance stationarity when the GARCH term is less than 1 (Shephard, 1996). EGARCH model was developed by Nelson (1991). In each case, the model adequacy is tested using the post diagnostic procedure as explained by (Tsay, 2002; Gourieroux, Jasiak, 2010; Engle 1982; and Bolleslev, 1986).

EGARCH model consists of two equations - mean and variance equations of food price inflation rate series:

Conditional Mean Equation:

The returns series are obtained as $R_{t}(k)=\log P_{t}-\log P_{t-k}=\log \left(\frac{P_{t}}{P_{t-k}}\right) * 100$. The log difference provides the basis to analyze the structural behaviour of the selected series. Given that $R_{t}, P_{t}$ and $P_{t-k}$ represent $R_{1}-R_{1} 6$, FPI/BDC/EXR/CIFCPI value at month ( $\mathrm{t}$ ) and FPI/BDC/EXR/CIFCPI value at the previous month ( $\mathrm{t}-\mathrm{k})$ in that order, the conditional mean equation is expressed as,

$$
\begin{aligned}
& R_{i t}=\alpha_{0}+\alpha_{1} R_{i t-q}+\varepsilon_{i t} \\
& R_{i t}=\alpha_{0}+\alpha_{1} R_{i t-q}+\alpha_{2} D_{i}+\varepsilon_{i t} \\
& \varepsilon_{t} \sim\left(0, \sigma_{t}^{2}\right)
\end{aligned}
$$

$\alpha_{0}$ is a constant (average of returns over the period), $\alpha_{1}$ and $\alpha_{2}$ are coefficients of one period lagged return series and the dummy variable (D) respectively. The dummy variable captures the structural break in returns series. Post and pre structural break dates are coded 1 and o respectively.

The conditional variance of EGARCH model $(1,1)$ model is specified as;

$$
\log \left(\sigma_{i t}^{2}\right)=\omega_{i}+\beta \log \left(\sigma_{i t-i}^{2}\right)+\gamma \frac{s_{i t-1}}{\sqrt{\sigma_{i t-1}^{2}}}+\alpha\left[\frac{\left|s_{i t-1}\right|}{\sqrt{\sigma_{i t-1}^{2}}}-\sqrt{\frac{2}{\pi}}\right],
$$

\subsubsection{Model Selection}

This is an important aspect of the study. Two-stage selection is required to select the best model for each returns series with which to estimate the spillover effect of exchange rate volatility on food price volatility. In the first step of selection, each returns series is modelled using EGARCH equation under the three distributions (Gaussian normal distribution, t-distribution and Generalized error distribution). At this stage, all returns series are modelled without recourse to structural break. Selection of the best model for each series is based on the pre-tests suggested by Engle 
(1982). The major selection criteria are Akaike Info Criterion (AIC), Schwarz Criterion (SC) and Hannan-Quinn Criterion (HQC) as well as maximum Log likelihood ratio (LLR). The rule is that the most efficient model has the least AIC, SC and HQC values. Each of the selected equations is deployed to model the returns series but with the inclusion of structural breakpoint. At the second stage of model selection, the results obtained from the estimation of EGARCH models with inclusion of structural breaks in the mean equation are compared to those without structural breakpoints accordingly. At this stage of selection, we relied strongly on LLR to compare the better fit of the EGARCH models estimated with or without structural breakpoints in the mean equations for each returns series.

Therefore, from the selected models, we attempt to;

(i) investigate the asymmetric volatility response to both positive and negative news;

(ii) assess the volatility persistence in food price volatility; and

(iii) examine the pass through effect of exchange rate (BDCRETURNS and EXRETURNS) volatility on conditional volatility of food prices in Nigeria.

\subsubsection{Spillover between Foreign Exchange Market and Food Markets}

This study adapts the EGARCH univariate approach to achieve objective 3. After accounting for both the correlation and volatility clustering properties, the conditional volatility of exchange rate $\mathrm{R}_{1}-\mathrm{R}_{9}\left(\sigma_{i t}^{2}\right)$ models earlier saved are later fed into each of EGARCH models estimated for the selected food series (R10-R16).

EGARCH conditional variance equation for the exchange rate spillover to food

$\log \sigma_{i t}^{2}=\omega_{i}+\beta \log \left(\sigma_{i t-i}^{2}\right)+\gamma \frac{s_{i t-1}}{\sqrt{\sigma_{i t-1}^{2}}}+\alpha\left[\frac{\left|s_{i t-1}\right|}{\sqrt{\sigma_{i t-1}^{2}}}-\sqrt{\frac{2}{\pi}}\right]+\delta_{1} \sigma_{i t}^{2}$

where $\omega, \beta, \gamma$, and $\alpha$ are parameters to be estimated. These parameters are defined as follows:

$\mathrm{i}=\mathrm{R}_{1}-\mathrm{R}_{1} 6$

$\gamma:=$ captures leverage effect;

$\gamma$ < o means conditional volatility of i responds to -ve shock more than +ve shock;

$\gamma$ : $>$ means conditional volatility of i responds to +ve shocks more than -ve shocks;

$\alpha=$ captures magnitude of conditional shocks on the conditional variance

$\beta=$ Persistence

$\mathrm{H}_{\circ}=\beta_{1}=\mathrm{o}($ No persistence $) ;$ and $\mathrm{H}_{1}=\beta_{1} \neq 0$

$\mathrm{H}_{\circ}=\gamma=\mathrm{o}$ (No leverage); and $\mathrm{H}_{1}=\gamma \neq 0$

Given that $R_{i t}$ is returns of the selected series $\left(\mathrm{R}_{1}-\mathrm{R}_{1} 6\right), R_{t-k}$ are lagged $R_{i t}, \varepsilon_{t}$ 
stands for error term (white noise). Therefore, $\omega_{i}, \alpha_{0}, \alpha_{1}, \alpha, \beta, \gamma$, and $\delta_{1}$ are parameters to be determined in each model.

\subsection{Model Estimation}

\subsubsection{Preliminary and Post Estimation Diagnostic Tests}

We began our estimation by assessing the descriptive statistics of both the level and the returns of selected series in block 1 (FPI, BDC and EXR) and CIFCPI. This is specifically to determine the mean, standard deviation, coefficient of variation of the returns series. The Jarque-Bera test provided information on the normality status of the selected series (not included on the table because of space). The Augmented Dickey-Fuller is used to ascertain that the selected returns series are stationary. This is necessary because in financial series, the possibility of non-stationarity is high and our model requires that the series are stationary to avoid spurious estimates. We modelled EGARCH under the three distributions, Gaussian normal (N-EGARCH), t-distribution (T-EGARCH), Generalized Error Distribution (Ged-EGARCH).

Unit root test is carried out on the disaggregated series $\left(R_{1}-R_{1} 6\right)$. The Augmented Dickey-Fuller (ADF) test is carried out on each of the returns series without consideration for structural breaks in the series to validate or otherwise the presence of unit root in the returns series. Similar test is also conducted using breakpoint unit root test (Augmented Dickey-Fuller - ADF). This is to consider the structural breaks in the series. Decision Rule: If the test statistics is below the critical value, then accept null, but reject it if otherwise.

The Ljung-Box-Pierce (null: no serial correlation in the series) and ARCH Lagrange Multiplier, ARCH -LM, (null: no ARCH effect in the series) tests are carried out on the residuals and residual squares respectively to ascertain the autocorrelation and volatility bunching in the selected series. The approach therefore, is that a decision threshold of $5 \%$ was set for the $\mathrm{P}$ values to either reject the null hypothesis or otherwise by the Ljung-Box and ARCH-LM tests. For each of the model, the rejection of null hypotheses by ARCH-LM test is an evidence that the volatility of the returns can be modelled by EGARCH model.

The importance of the post estimation diagnostic test is to validate the performance of the EGARCH model. We rely on the ARCH-LM test to ensure that the EGARCH model sufficiently account for all the volatility structure in each of the selected series. ARCH-LM (null: no ARCH effect in the series), and we also follow the decision threshold of $5 \%$ for the P values to either reject or not to reject the null hypotheses. Once there is no basis to reject the null hypotheses by ARCH-LM tests, it implies that the volatility structure of the series has been efficiently modelled by the EGARCH models. 


\subsubsection{Maximum Log-likelihood Function}

The Quasi Maximum Log Likelihood (QML) estimation was used to achieve parameter estimates for both conditional mean and variance equations. Gaussian (normal) distribution and BFGS-BOUNDS were the choice for parameter estimation because it converges for optimum quadratic Taylor expansion.

\section{RESULTS AND DISCUSSION}

\subsection{Descriptive Statistics}

Table 1. presents the descriptive statistics for the returns of selected series. Based on the values of standard deviation, the BDCRETURNS (1.81) is more volatile than EXRETURNS (1.27) while FPIRETURNS (1.10) spikes higher than CIFCPIRETURNS (0.80). Using the coefficient of variation to describe the volatility of only the returns series, CPIRETURNS (38.2\%) is the more volatile than CIFCPIRETURNS $(5 \%)$. On exchange rate, volatility of BDCRETURNS $(26.5 \%)$ rises higher than that of EXRETURNS $(17 \cdot 7 \%)$. However, the differentials in the size of observations, simplicity of the method and its disregard for time trend make it difficult to draw conclusion on whether or not these volatility results reflect reality about the risk in food market. Further estimation of conditional volatility is required to validate these findings. On the other hand, a random normal distribution is expected to have a symmetrical distribution of observations with bell like peak. All the returns series defy this pattern. FPIRETURNS and CIFCPIRETURNS are skewed to the right, BDCRETURNS and EXRETURNS are skewed leftwards. The kurtosis value for each of the series shows that the leptokurtic attributes of each of the returns series is well pronounced. The attributes suggest that the series deviates from normal distribution. The Jarue-Bera test confirms that each of the returns series is not normally distributed. The observed structure in each of the returns series indicates the presence of volatility. Following these outputs, the returns series are disaggregated as $R_{1}-R_{1} 6$.

Table 1. Descriptive statistics of data series used in the analysis

\begin{tabular}{|c|c|c|c|c|c|c|c|c|c|}
\hline Series & $\begin{array}{c}\text { Sample } \\
\text { period }\end{array}$ & $\mathbf{N}$ & Mean & $\begin{array}{l}\text { Std. } \\
\text { Dev. }\end{array}$ & $\begin{array}{l}\text { Coef. } \\
\text { Var. }\end{array}$ & Skewness & Kurtosis & $\begin{array}{c}\text { Jarque- } \\
\text { Bera }\end{array}$ & Probability \\
\hline BDC & $\begin{array}{r}1991 \mathrm{Mo1}- \\
2017 \mathrm{Mo8}\end{array}$ & 320 & 135.21 & 82.37 & $1.64,1$ & 1.80644 & $7 \cdot 94: 2776$ & $499 \cdot 7^{8} 57$ & 0.0000 \\
\hline BDCRETURNS & $\begin{array}{r}1991 \mathrm{Mo1}- \\
2017 \mathrm{M} 88\end{array}$ & 319 & -0.48 & 1.81 & 0.265 & -0.92808 & 8.873882 & 504.3892 & 0.0000 \\
\hline CPI & $\begin{array}{r}1990 \mathrm{Mo1}- \\
2017 \mathrm{M}_{12}\end{array}$ & 336 & $139 \cdot 7^{3}$ & 43.45 & 3.216 & 0.708397 & 2.16525 & 37.8576 & 0.0000 \\
\hline CPIRETURNS & $\begin{array}{r}1990 \mathrm{Mol}- \\
2017 \mathrm{M} 12\end{array}$ & 335 & 0.42 & 1.10 & 0.382 & $0.493 \circ 37$ & $5 \cdot 4,83994$ & 99.69836 & 0.0000 \\
\hline
\end{tabular}




\begin{tabular}{|l|r|r|r|r|r|r|r|r|r|}
\hline \multicolumn{1}{|c|}{ Series } & $\begin{array}{c}\text { Sample } \\
\text { period }\end{array}$ & N & Mean & $\begin{array}{r}\text { Std. } \\
\text { Dev. }\end{array}$ & $\begin{array}{c}\text { Coef. } \\
\text { Var. }\end{array}$ & Skewness & Kurtosis & $\begin{array}{c}\text { Jarque } \\
\text { Bera }\end{array}$ & Probability \\
\hline CIFCPI & $\begin{array}{r}2009 \mathrm{M} 11- \\
201612\end{array}$ & 86 & 144.97 & 30.48 & 4.756 & 0.5411 & 2.5568 & 4.8997 & 0.0863 \\
CIFCPIRETURNS & $\begin{array}{r}2009 \mathrm{M} 11- \\
201612\end{array}$ & 85 & -0.04 & 0.80 & 0.050 & 0.0017 & 10.8844 & 220.1649 & 0.0000 \\
EXR & $\begin{array}{r}1995 \mathrm{Mo1}- \\
2017 \mathrm{Mo8} \\
1995 \mathrm{Mo1}- \\
2017 \mathrm{Mo8}\end{array}$ & 272 & 138.347 & 50.64 & 2.732 & 1.6917 & 6.5757 & 247.64 & 0.0000 \\
EXRRETURNS & 27244 & 1.27 & 0.177 & -2.1448 & 29.4165 & 8089.339 & 0.000 \\
\hline
\end{tabular}

Note: All variables are expressed in logarithmic first-difference form. Source: Data Analysis, 2018.

Figure 1. shows the graphical representations of the structure in both the level and returns series. There is clear evidence of volatility clustering in the returns series. The FPIRETURNS and EXRETURNS peaked in 2008. A period that coincides with global financial crisis. The peak of volatility in BCDRETURNS is witnessed between 93/94. Although volatility in BCDRETURNS is also observed to be high in 2008 and 2016 but not as high as the peak period. The volatility clustering in CIFCPIRETURNS is evident in 2011. At that period, the world witnessed a mild global food crisis as part of hangover from 2008 global financial crisis. Experts linked that mild crisis to the counter effects of some restrictive policies taken by some countries to prevent pass through effects from international market to domestic markets. The spikes are the market responses to both government fiscal expansion and contractionary measures.

Figure 1.: Graphical representation of Combined Level and Returns Series (CPI,CFPI, BDC and EXR)
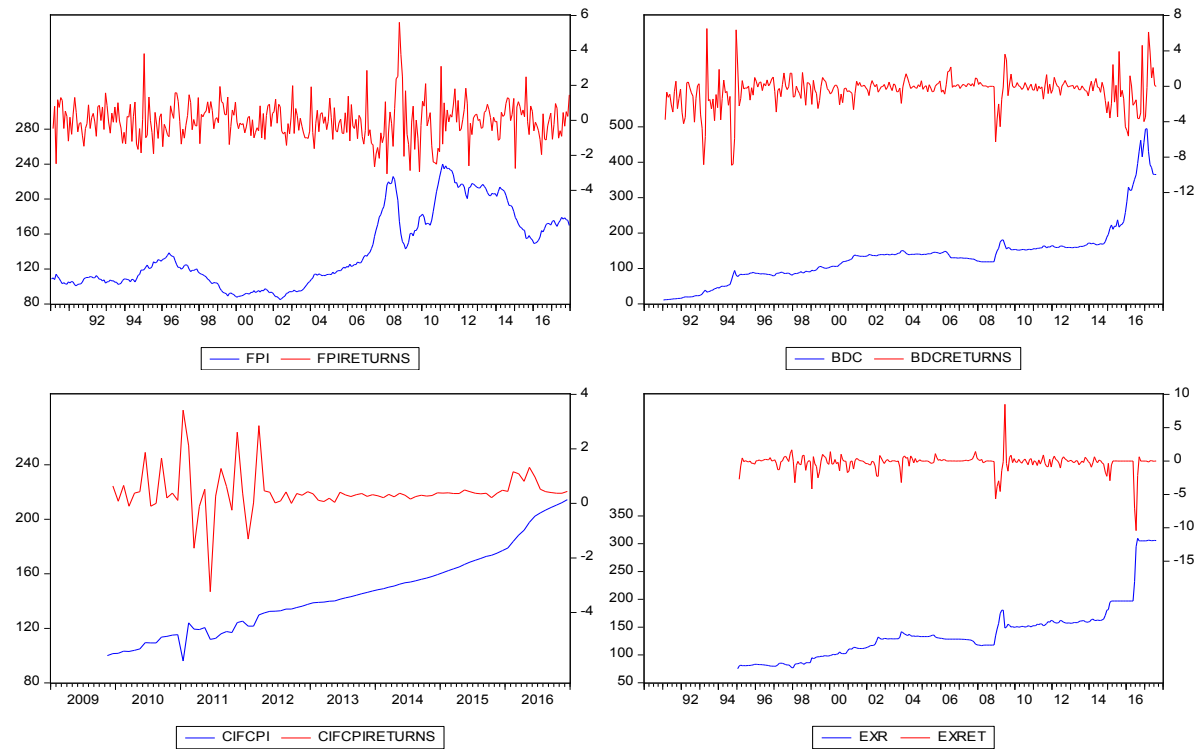

Source: Data Analysis, 2018. 


\subsection{Unit Root Test}

The results of the unit root test are presented in Table 2. The stationarity of the series is a pre-requisite for estimating GARCH models. The results reveal that all the returns series are found to be stationary at level. This evidence is obtained from the $\mathrm{P}$-values which indicate that the null for each of the series can be rejected in favour of the alternate hypothesis at $1 \%$ significant level.

Table 2.: Unit Root Test

\begin{tabular}{|c|c|c|c|c|c|c|c|c|}
\hline Code & $\begin{array}{c}\text { Variable } \\
\text { Description } \\
\text { (Only Returns } \\
\text { Series are } \\
\text { modelled) }\end{array}$ & $\begin{array}{l}\text { Break } \\
\text { Date }\end{array}$ & Period & $\begin{array}{c}\text { Test of } \\
\text { Unit } \\
\text { Root }\end{array}$ & $\begin{array}{c}\text { Test Sta- } \\
\text { tistics }\end{array}$ & $\begin{array}{c}\text { Critical } \\
\text { Statistics } \\
(\mathbf{1 \% )}\end{array}$ & PValue & $\begin{array}{l}\text { Source } \\
\text { of Data }\end{array}$ \\
\hline $\mathrm{R}_{1}$ & $\begin{array}{r}\text { Block 1: Pool } \\
\text { BDCRETURNS } \\
\text { without includ- } \\
\text { ing dummy for } \\
\text { structural break } \\
\text { in Mean Equa- } \\
\text { tion }\end{array}$ & & $\begin{array}{r}\text { 1991Mo1 } \\
- \\
2017 \mathrm{Mo} 8\end{array}$ & $\mathrm{I}(\mathrm{o})$ & -12.1142 & $-3.9917^{*}$ & 0.0000 & CBN \\
\hline $\mathrm{R}_{2}$ & $\begin{array}{r}\text { Block 1: Pool } \\
\text { BDCRETURNS } \\
\text { with dummy for } \\
\text { structural break } \\
\text { included in } \\
\text { Mean Equation }\end{array}$ & 1994Mio & $\begin{array}{r}\text { 1991Mo1 } \\
- \\
\text { 2017Mo8 }\end{array}$ & I(o) & -14.2266 & -4.949 & 0.01 & \\
\hline *R3 & $\begin{array}{r}\text { Block 1: POST } \\
\text { structural break } \\
\text { date in BDCRE- } \\
\text { TURNS }\end{array}$ & & $\begin{array}{r}1994 \mathrm{M}_{11} \\
- \\
2008 \mathrm{M} 10\end{array}$ & I(o) & -13.699 & $-4.0139 *$ & 0.0000 & \\
\hline $\mathrm{R}_{4}$ & $\begin{array}{r}\text { Block 2: } \\
\text { BDCRETURNS } \\
\text { without struc- } \\
\text { tural break in } \\
\text { the Mean Equa- } \\
\text { tion }\end{array}$ & & $\begin{array}{r}2009 \mathrm{M}_{11} \\
- \\
2016 \mathrm{M}_{12}\end{array}$ & $1(0)$ & -8.9034 & -4.4635 & 0.000 & \\
\hline $\mathrm{R}_{5}$ & $\begin{array}{r}\text { Block 2: } \\
\text { BDCRETURNS } \\
\text { with structural } \\
\text { break in the } \\
\text { Mean Equation }\end{array}$ & $2015 \mathrm{M}_{12}$ & $\begin{array}{r}2009 \mathrm{M}_{11} \\
- \\
2016 \mathrm{M} 12\end{array}$ & $1(0)$ & -9.5997 & -4.9491 & 0.010 & \\
\hline R6 & $\begin{array}{l}\text { Block 1: EXRE- } \\
\text { TURNS without } \\
\text { Break Date }\end{array}$ & & $\begin{array}{r}1995^{\mathrm{Mo1}} \\
- \\
2017 \mathrm{Mo} 8\end{array}$ & $1(0)$ & -10.6647 & -3.9925 & 0.0000 & CBN \\
\hline $\mathrm{R}_{7}$ & $\begin{array}{c}\text { Block 1: EXRE- } \\
\text { TURNS with } \\
\text { Break Date }\end{array}$ & $2016 \mathrm{Moz}$ & $\begin{array}{r}1995^{\mathrm{M}}{ }^{-} \\
\text {2017 Mo8 }\end{array}$ & $1(0)$ & -13.8220 & -4.9491 & 0.000 & \\
\hline R8 & $\begin{array}{r}\text { Block 2: EXRE- } \\
\text { TURNS without } \\
\text { Break Date }\end{array}$ & & $\begin{array}{r}2009 \mathrm{M}_{11} \\
- \\
2016 \mathrm{M}_{12}\end{array}$ & $1(0)$ & -6.847 & -4.0696 & 0.000 & \\
\hline
\end{tabular}




\begin{tabular}{|c|c|c|c|c|c|c|c|c|}
\hline Code & $\begin{array}{c}\text { Variable } \\
\text { Description } \\
\text { (Only Returns } \\
\text { Series are } \\
\text { modelled) }\end{array}$ & $\begin{array}{c}\text { Break } \\
\text { Date }\end{array}$ & Period & $\begin{array}{l}\text { Test of } \\
\text { Unit } \\
\text { Root }\end{array}$ & $\begin{array}{c}\text { Test Sta- } \\
\text { tistics }\end{array}$ & $\begin{array}{c}\text { Critical } \\
\text { Statistics } \\
(1 \%)\end{array}$ & PValue & $\begin{array}{l}\text { Source } \\
\text { of Data }\end{array}$ \\
\hline R9 & $\begin{array}{l}\text { Block 2: EXRE- } \\
\text { TURNS with } \\
\text { Break Date }\end{array}$ & $2016 \mathrm{M} \circ 5$ & $\begin{array}{r}2009 \mathrm{M}_{11} \\
- \\
2016 \mathrm{M}_{12}\end{array}$ & $1(0)$ & $-8.404^{3}$ & -4.9491 & 0.010 & \\
\hline Rio & $\begin{array}{r}\text { Block 1: Pool } \\
\text { FPIRETURNS } \\
\text { without includ- } \\
\text { ing dummy for } \\
\text { structural break } \\
\text { in Mean Equa- } \\
\text { tion }\end{array}$ & & $\begin{array}{r}1990 \mathrm{Mo1} \\
- \\
2017 \mathrm{M}_{12}\end{array}$ & $\mathrm{I}(\mathrm{o})$ & -7.246 & $-3.9912^{*}$ & 0.000 & FAO \\
\hline Ri1 & $\begin{array}{r}\text { Block 1: Pool } \\
\text { FPIRETURNS } \\
\text { with structural } \\
\text { break dummy } \\
\text { included in } \\
\text { Mean Equation }\end{array}$ & $2008 \mathrm{M} 10$ & $\begin{array}{r}1990 \mathrm{Mo1} \\
- \\
2017 \mathrm{M} 12\end{array}$ & $\mathrm{I}(\mathrm{o})$ & -8.9811 & -4.9491 & 0.010 & \\
\hline${ }^{*} \mathrm{R} 12$ & $\begin{array}{r}\text { Block 1: Pre } \\
\text { structural break } \\
\text { date in CPIRE- } \\
\text { TURNS }\end{array}$ & & $\begin{array}{r}\text { 1994M11 } \\
- \\
2008 \mathrm{M} 10\end{array}$ & I(o) & -3.8922 & $-3.4372^{* *}$ & 0.014 & \\
\hline Ri3 & $\begin{array}{r}\text { Block 2: FPIRE- } \\
\text { TURNS series } \\
\text { (Without Break } \\
\text { Date included) }\end{array}$ & & $\begin{array}{r}2009 \mathrm{M}_{11} \\
- \\
2016 \mathrm{M} 12\end{array}$ & $\mathrm{I}(\mathrm{o})$ & -7.8730 & -4.0696 & 0.0000 & \\
\hline Ri4 & $\begin{array}{r}\text { Block 2: CIF- } \\
\text { CPIRETURNS } \\
\text { with structural } \\
\text { Break included } \\
\text { in the Mean } \\
\text { Equation }\end{array}$ & 2011Mo6 & $\begin{array}{r}2009 \mathrm{M}_{11} \\
- \\
2016 \mathrm{M}_{12}\end{array}$ & I(o) & $-5.55^{\circ 2}$ & -3.5144 & 0.0000 & NBS \\
\hline $\mathrm{R}_{15}$ & $\begin{array}{r}\text { Block 2: CIF- } \\
\text { CPIRETURNS } \\
\text { without includ- } \\
\text { ing structural } \\
\text { Break in Mean } \\
\text { Equation }\end{array}$ & & $\begin{array}{r}2009 \mathrm{M}_{11} \\
- \\
2016 \mathrm{M} 12\end{array}$ & $\mathrm{I}(\mathrm{o})$ & -10.7127 & -4.9491 & $<0.01$ & \\
\hline Ri6 & $\begin{array}{r}\text { Block 2: FPIRE- } \\
\text { TURNS series } \\
\text { (With Break } \\
\text { Date included) }\end{array}$ & $2015 \mathrm{Mo8}$ & $\begin{array}{r}2009 \mathrm{M}_{11} \\
- \\
2016 \mathrm{M} 12\end{array}$ & $\mathrm{I}(\mathrm{o})$ & $-8.3 \circ 7^{2}$ & -4.9491 & $<0.01$ & FAO \\
\hline
\end{tabular}

Note: *POST structural break date in BDCRETURNS/ Pe structural date in CPIRETURNS in block 1 (both are independent of whether or not structural breakpoint is included).

Source: Data Analysis, 2018. 


\subsection{Ljung-Box-Pierce and ARCH Lagrange Multiplier Tests}

Table 3. contains the outputs of Ljung and ARCH tests. Notably, the output of ARCH Lagrange Multiplier test null hypothesis is rejected at 1 lag but R6, R8 \& R9 reject null hypotheses at lag 2 while $R_{14} \& R_{1} 5$ reject null hypotheses at lag 6. It implies that the presence of ARCH effect in the returns series gives the sufficient condition for the series to be modelled using EGARCH. The other necessary condition is the presence of long memory in the returns series. The Ljung-Box-Pierce test reveals the evidence of strong autocorrelation (long memory recall) in all the series except $\mathrm{R} 3, \mathrm{R}_{5}, \mathrm{R}_{6}, \mathrm{R}_{7}, \mathrm{R} 8, \mathrm{R}_{9}, \mathrm{R}_{11}, \mathrm{R}_{1} 3$ and $\mathrm{R}_{1} 6$, where the long memory attribute of the series is very weak. The outputs of the ARCH-LM are convincing reasons to estimate these series using EGARCH models hence, we proceeded to model selection using the selection criteria (AIC, SIC and HQG). The best model is selected from among those estimated under the three distributions: Gaussian normal (N-EGARCH), tdistribution (T-EGARCH), Generalized Error Distribution (Ged-EGARCH). The selected model is posted accordingly for each return series $\left(\mathrm{R}_{1}-\mathrm{R}_{1} 6\right)$ in Table 3.

Table 3.: Output of ARCH LM Test, Liung-Box-Pierce and Model Selection

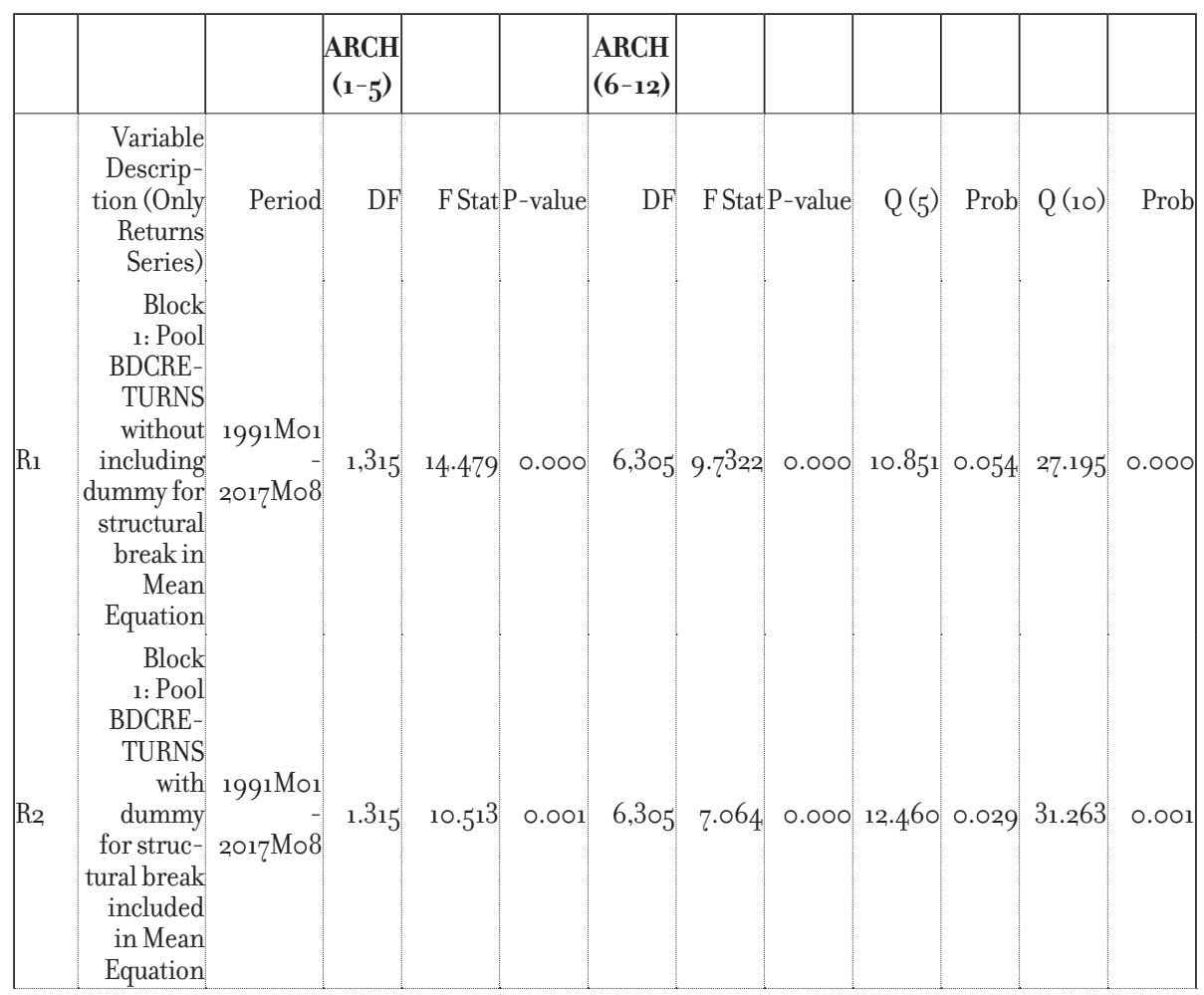




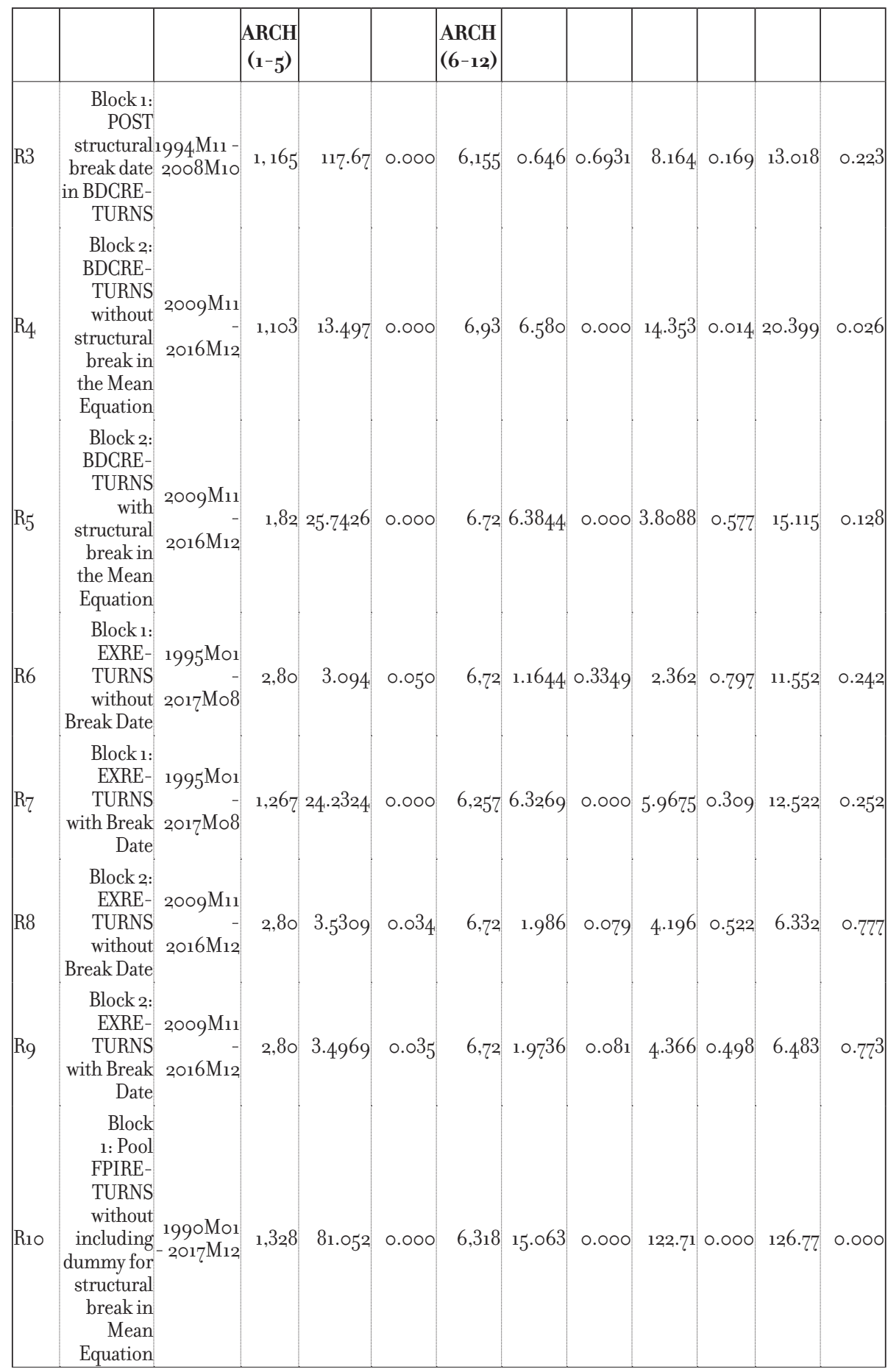




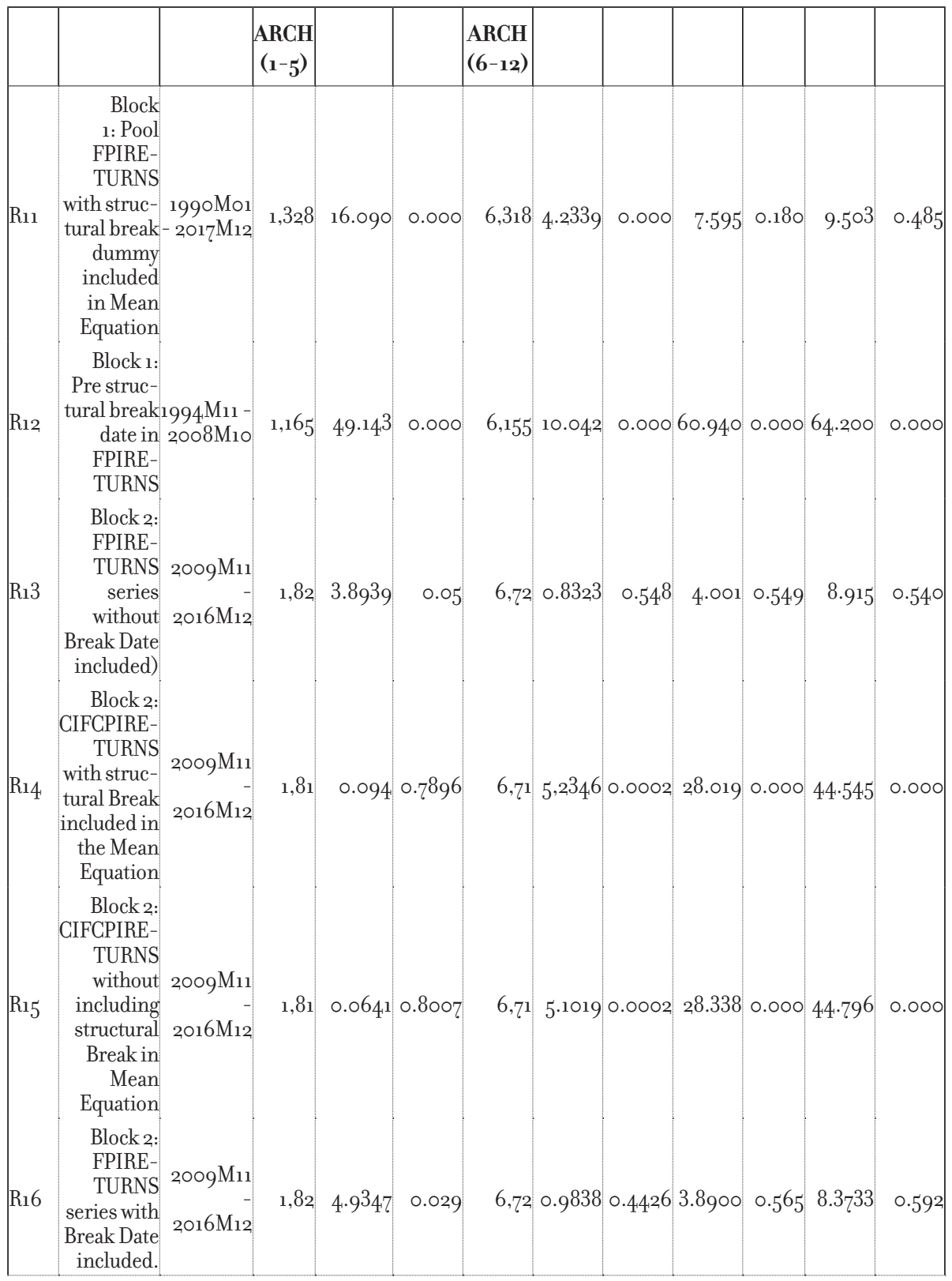

Source: Data Analysis, 2018. 


\subsection{Leverage Effect and Volatility Persistence in estimated EGARCH Models}

The dynamics in both food and forex markets are reflections of the behavior of economic agents therein including the government agents who craft and implement macroeconomic-stability-driven policies. Across and along food value chains, news/ innovations are generated. Either positive or negative, the news has a way of influencing movement of food price and exchange rate series (structural and leverage effects). This may prolong or reduce the persistence in volatility dynamics. Appendix I presents the outputs of EGARCH model (with and without structural breakpoints included in the mean equation) showing leverage effect and volatility persistence. The selected equations are highlighted in yellow. Among these, R2 (Block 1: Pool BDCRETURNS with dummy for structural break included in Mean Equation), $\mathrm{R}_{5}$ (Block 2: BDCRETURNS with structural break in the Mean Equation), R9 (Block 2: EXRETURNS with Break Date) and R12 (Block 1: POST structural break date in BDCRETURNS) have leverage effects that are statistically significant at $1 \%, 1 \%, 5 \%$ and $10 \%$ respectively. It implies negative shocks, more than the positive shocks, increase conditional volatility in $\mathrm{R}_{2}, \mathrm{R}_{5}$ and $\mathrm{R}_{9}$. On the contrary, positive news creates more shocks to conditional volatility of $\mathrm{R}_{12}$. Given the threshold of 0.5 , above is high persistence while below is low persistence. Therefore, in Appendix 1, volatility persistence is high in all the selected models except in R12 (Block 1: POST structural break date in BDCRETURNS). The persistence of volatility gives clue about the speed it takes for shocks to decay off. At high persistence, shocks to conditional variation decay off very slowly but reverse is the case with low persistence. It implies that a high degree of price volatility persistence in the selected series (food price and exchange rate) is an indication that the perception about low return lingers for a longer time as opined by McAleer et al. (2007). The implication is that farmers factor this risk perception by setting their prices above the mean price value. This is capable of altering price competitiveness at international market.

\subsection{Exchange Rate Volatility (Forex) Spillover to Food Price Volatility}

The utmost goal of any economy is to, at least, achieve balanced trade if favourable trade is not possible. This prevents household from trading-off their welfare. For a country that depends on food importation to augment her inadequate domestic food supply to achieve and sustain her household welfare, her trade policies must be well-thought-out. Stability in forex market is one outcome of these efforts. However, achieving stability in the forex market in Nigeria has been a herculean task. It is in view of this, this study investigates the instability in Nigerian forex market and its spillover effect on food prices in Nigeria. The outputs of exchange rate volatility spillover to food market are presented in Appendix II. The selected EGARCH 
model for each returns series is estimated to capture the transmission from forex (BDCRETURNS and EXRETURNS) volatility to food price volatility. In block 1, there is evidence of significant transmission from $\mathrm{R}_{7}$ (Block 1: EXRVOL with Break Date) to Rıı (Block 1: Pool FPIRETURNS with structural break dummy included in Mean Equation). Findings also reveal that conditional volatility of R14 (Block 2: CIFCPIRETURNS with structural Break included in the Mean Equation) is affected by $\mathrm{R}_{5}$ (Block 2: BDCVOL with structural break in the Mean Equation) and R9 (Block 2: EXRETURNS with Break Date). The fact that the volatility in price of dollar at interbank market (EXRVOL) affects the conditional volatility of each of FPIRETURNS and CIFCPIRETURNS, it implies that the instability in inter-bank exchange market strongly affects food prices. Also, BDCVOL and EXRVOL strongly affect imported food prices in Nigeria. The spillover may persist as the country increases her food imports in the light of instability in international food market.

\section{CONCLUSIONAND RECOMMENDATION}

This study reveals that negative news more than positive news increases volatilities in the selected series. There is leverage effect in the conditional volatility of $\mathrm{R}_{2}$, $\mathrm{R}_{5}$, R9 but positive news hypes conditional volatility in $\mathrm{R}_{12}$. The forex market (BDC and Inter-Bank Market) is strongly affected by negative news. On speed of adjustment in the volatilities of food price and exchange rate, there is evidence that it takes a long period for shock to fade away in all the selected returns series except $\mathrm{R}_{12}$. Such high persistence predisposes the markets (forex and food) to a prolonged perception of low returns hence, food producers/traders set prices above the mean value to avert risk. Consequently, food price inflation increases as opined by Sehkar, Roy and Bhatt (2017). This is not a good condition for market stability. Output on Appendix II provides the evidence that exchange rate volatility significantly spillover to food price market. This influence is more pronounced on the price volatility of imported food. Therefore, policies geared towards the stability of forex market can minimize the price volatility of imported food. The presence of structural shifts in the series is an evidence of impact of inconsistent macroeconomic policies implemented to achieve macroeconomic objectives including market stability. It aligns with the findings of Salisu and Fasanya (2013), Salisu and Oloko (2015), and Fasanya and Adekoya (2017). Therefore, consistent implementation of well thought-out macroeconomic policies particularly on forex, food and agriculture will hugely mitigate against food market risk and enhance household food security. This call becomes apt because household spend an average of $60 \%$ of household income on food. Achieving stability in food market will not only enhance household long term plan but also budget discipline. Therefore, when household food security is achieved, welfare is enhanced and more members of the households can contribute to economic growth. 


\section{REFERENCES}

Organisation des Nations Unies pour l'alimentation et l'agriculture. Safeguarding food security in volatile global markets. Edited by Adam Prakash. Food and Agriculture Organization of the United Nations, 2011.

Agunbiade, B. O., T. E. Mafimisebi, and E. S. Ikuemonisan. "Pricing Contacts and Price Leadership in the Market for Imported Rice in Southwest Nigeria." Rice Genomics and Genetics 6 (2015).

Akor, G. "Climate change and agriculture: The Nigerian story". Conference presentation FES Ghana, Accra, 10 - 11 (April 2012).

Anderson, Margot, and Philip Garcia. "Exchange rate uncertainty and the demand for US soybeans." American Journal of Agricultural Economics 71, no. 3 (1989): 721-729

Jain, Ajeet, and Sascha Strobl. "The effect of volatility persistence on excess returns." Review of Financial Economics 32, no. 1 (2017): 58-63

Alom, Fardous, Bert Ward, and Baiding Hu. "Spillover effects of World oil prices on food prices: evidence for Asia and Pacific countries." In Proceedings of the $52 n$ Annual Conference New Zealand Association of Economists, vol. 29. 2011.

Ismail, Andleeb, Hajra Ihsan, Saud Ahmad Khan, and Munazza Jabeen. "Price Volatility of Food and Agricultural Commodities: A Case Study of Pakistan." Journal of Economic Cooperation \& Development 38, no. 3 (2017): $77^{-120}$

Assefa, Tsion Taye, Miranda PM Meuwissen, and Alfons GJM Oude Lansink. "Price volatility transmission in food supply chains: a literature review." Agribusiness 31, no. 1 (2015): 3-13. Barnett, Barry J., Christopher B. Barrett, and Jerry R. Skees. "Poverty traps and index-based risk transfer products." World Development 36, no. 10 (2008): 1766-1785

Bobola, O. M., T. E. Mafimisebi, and E. S. Ikuemonisan. "Price Fluctuations, Linkages and Causality in the Nigerian Beef Market." Journal of Fisheries \& Livestock Production (2015).

Bellemare, Marc F., Christopher B. Barrett, and David R. Just. "The welfare impacts of commodity price volatility: evidence from rural Ethiopia." American Journal of Agricultural Economics 95, no. 4 (2013): $877^{-899}$

Bollerslev, Tim. "Generalized autoregressive conditional heteroskedasticity." Journal of econometrics 31, no. 3 (1986): 3 o $7-327$

Campiche, Jody L., Henry L. Bryant, James W. Richardson, and Joe L. Outlaw. "Examining the evolving correspondence between petroleum prices and agricultural commodity prices." In The American agricultural economics association annual meeting, Portland, OR, vol. 29, (2007): 1-15

Chit, Myint Moe, Marian Rizov, and Dirk Willenbockel. "Exchange rate volatility and exports: new empirical evidence from the emerging East Asian Economies." World Economy 33, no. 2 (2010): 239263

Cornia, Giovanni Andrea, Laura Deotti, and Maria Sassi. "Food price volatility over the last decade in Niger and Malawi: extent, sources and impact on child malnutrition." Documento de trabajo 2012-002 (2012).

Cox, John C., and Stephen A. Ross. "The valuation of options for alternative stochastic processes." Journal of financial economics 3, no. 1-2 (1976): 145-166

Coyle, Barry T. "Risk aversion and price risk in duality models of production: a linear mean-variance approach." American Journal of Agricultural Economics 74, no. 4 (1992): 849-859 
De Vita, Glauco, and Andrew Abbott. "The impact of exchange rate volatility on UK exports to EU countries." Scottish Journal of Political Economy51, no. 1 (2004): 62-81

Dehn, Jan. The effects on growth of commodity price uncertainty and shocks. The World Bank, 2000.

Syampaku, Em, and Taiwo Mafimisebi. "Responsiveness of Spatial Price Volatility To Increased Government Participation In Maize Grain And Maize Meal Marketing In Zambia." In 2014, Annual Meeting, July 27-29, 2014, Minneapolis, Minnesota, no. 174858. Agricultural and Applied Economics Association, 2014.

Edamisan Stephen Ikuemonisan: "Analysis of Inflation Volatility for Fish and Meat Markets in Nigeria using ARMA and GARCH Types". International Journal of Agriculture and Development Studies (IJADS) Vol. 2 No. 1 (2017): $116-131$

Engle, Robert F. "Autoregressive conditional heteroscedasticity with estimates of the variance of United Kingdom inflation." econometrica 5o, no. 4. (1982): 987-1007

Ezzati, Parinaz. Analysis of Volatility Spillover Effects: Two-Stage Procedure Based on a Modified Garch-M. Business School-Economics University of Western Australia, 2013.

Fatuase, A.I., Ehinmowo, O.O., Oparinde, L.O. and Omonijo, G.A. "Effect of Agriculture and Health Expenditures on the Economic Growth in Nigeria". Journal of Biology, Agriculture and Healthcare, 6(7) (2016): $48-57$

FAO, IFAD, and UNICEF. "WFP, WHO: The State of Food Security and Nutrition in the World 2017." Building Resilience for Peace and Food Security. Rome, FAO (2017).

García-Germán, Sol, Cristian Morales-Opazo, Alberto Garrido, Mulat Demeke, and I. Bardaj. "Literature review of impacts of food price volatility on consumers in developed and developing countries." ULYSSES Understanding and Coping with Food Markets voLatilitY towards More Stable World and EU Food SystEmS (2013).

Gilbert, Christopher L., and C. Wyn Morgan. "Food price volatility." Philosophical Transactions of the Royal Society B: Biological Sciences 365, no. 1554 (2010): 3023-3034

Gourieroux, Christian, and Joann Jasiak. "Local likelihood density estimation and Value-atRisk." Journal of Probability and Statistics 2010 (2010).

Green, William H. "Econometric Analysis (7 th)." (2007).

Frank, Julieta, and Philip Garcia. "Bid-ask spreads, volume, and volatility: Evidence from livestock markets." American Journal of Agricultural Economics 93, no. 1 (2011): 209-225

Hendrix, Cullen, and Henk-Jan Brinkman. "Food insecurity and conflict dynamics: Causal linkages and complex feedbacks." Stability: International Journal of Security and Development 2, no. 2 (2013).

HLPE, Price. "volatility and food security a report by The High Level Panel of Experts on Food Security and Nutrition." Roma, July (2011).

IFPRI, Global Food Policy Report 2012, Washington, DC: International Food Policy Research Institute (2013)

IMF, OECD, and WFP UNCTAD. "Price Volatility in Food and Agricultural Markets: Policy Responses." Food and Agricultural Organization. JOHNSON JJ(2011): 1999-2008

Nwoko, Ijeoma C., Goodness C. Aye, and Benjamin C. Asogwa. "Effect of oil price on Nigeria's food price volatility." Cogent Food \& Agriculture 2, no. 1 (2016): 114,6057

Fasanya, Ismail O., and Oluwasegun B. Adekoya. "Modelling inflation rate volatility in Nigeria with 
structural breaks." CBN Journal of Applied Statistics 8, no. 1 (2017): 175-193

Fogarasi, Jozsef. "The effect of exchange rate volatility upon foreign trade of Hungarian agricultural products." Studies in Agricultural Economics 113, no. 1 (2011).

Kafle, Kashi Ram. "Exchange rate volatility and bilateral agricultural trade flows: the case of the United States and OECD countries." (2011).

Brown, Keith C., W. Van Harlow, and Seha M. Tinic. "Risk aversion, uncertain information, and market efficiency." Journal of financial Economics22, no. 2 (1988): 355-385

Kenyon, David E. "Producer ability to forecast harvest corn and soybean prices." Review of Agricultural Economics 23, no. 1 (2001): 151-162

Khan, M. Akhtar, and Glenn A. Helmers. "Causality, Input Price Variability, and Structural Changes in the US Livestock-Meat Industry." In Western Agricultural Economics Association Meeting, Reno Nevada July, (1997): 13-16

Khiyavi, P. K., R. Moghaddasi, B. Eskandarpur, and N. Mousavi. "Spillover effects of agricultural products price volatilities in Iran (Case Study: Poultry Market)." Journal of Basic and Applied Scientific Research 2, no. 8 (2012): 7906-7914

McAleer, Michael, Felix Chan, and Dora Marinova. "An econometric analysis of asymmetric volatility: theory and application to patents." Journal of Econometrics 139, no. 2 (2007): 259-284.

Mgbenka, R. N., E. N. Mbah, and C. I. Ezeano. "A review of small holder farming in Nigeria: Need for transformation." Agricultural Engineering Research Journal 5, no. 2 (2015): 19-26

Minot, Nicholas. "Food price volatility in sub-Saharan Africa: Has it really increased?." Food Policy 45 (2014): $45^{-} 5^{6}$

Mandelbrot, Benoit B. "The variation of certain speculative prices." In Fractals and scaling in finance, pp. 371-418. Springer, New York, NY, 1997 .

Moledina, AmyazA., Terry L. Roe, and Mathew Shane. "Measuring commodity price volatility and the welfare consequences of eliminating volatility." In Annual meeting, August, pp. 1-4. 2004.

Akbar, Muhammad, and Abdul Jabbar. "Impact of macroeconomic policies on national food security in Pakistan: simulation analyses under a simultaneous equations framework." Agricultural Economics/ Zemedelska Ekonomika 63, no. 10 (2017).

Nelson, Daniel B. "Conditional heteroskedasticity in asset returns: Anew approach." Econometrica: Journal of the Econometric Society (1991): $347-370$

Newbery, David M. "The theory of food price stabilisation." The Economic Journal 99, no. 398 (1989): $1065^{-1082}$

Apergis, Nicholas, and Anthony Rezitis. "Food price volatility and macroeconomic factors: Evidence from GARCH and GARCH-X estimates." Journal of Agricultural and Applied Economics 43, no. 1 (2011): 95110

Maurice, Noemie, and Junior Davis. "Unravelling the underlying causes of price volatility in world coffee and cocoa commodity markets." (2011).

Offutt, Susan E., and David Blandford. An evaluation of alternative indicators of commodity instability. No. 183825. Cornell University, Department of Applied Economics and Management, 1981.

Ogundipe, Adeyemi, Paul Ojeaga, and Oluwatomisin Ogundipe. "Estimating the long run effects of exchange rate devaluation on the trade balance of Nigeria." (2013). 
Omojimite, Benson U., and Godwin Akpokodje. "A comparative analysis of the effect of exchange rate volatility on exports in the CFA and non-CFA countries of Africa." Journal of Social Sciences 24, no. 1 (2010): 23-31

Osarumwense, O. I., and E. I. Waziri. "Modelling Monthly Inflation Rate Volatility, using Generalised Autoregressive Conditionally Heteroscedastic (GARCH) Models. Evidence from Nigeria." Australian Journal of Basic and Applied Sciences7, no. 7 (2013): 991-998

Ojogho, Osaihiomwan, and Robert Awotu Egware. "Price Generating Process And Volatility In Nigerian Agricultural Commodities Market." International Journal of Food and Agricultural Economics 3, no. 4 (2015): 55

Ott, Hervé. "Fertilizer markets and their interplay with commodity and food prices." Report for the European Commision Join Research Centre, Brussels (2012).

Pindyck, Robert S. "Volatility and commodity price dynamics." Journal of Futures Markets: Futures, Options, and Other Derivative Products 24, no. 11 (2004): 1029-1047

Piot-Lepetit, Isabelle. "Price volatility and price leadership in the EU beef and pork meat market." In Methods to analyse agricultural commodity price volatility, pp. 85-105. Springer, New York, NY, 2011.

Rabobank. "Rethinking The Food and Agribusiness Supply Chain; Impact of Agricultural Price Volatility on Sourcing Strategies." (2011).

Cont, Rama. "Empirical properties of asset returns: stylized facts and statistical issues." (2001): 223-236

Ramey, Garey, and Valerie A. Ramey. Cross-country evidence on the link between volatility and growth. No. w4959. National bureau of economic research, 1994.

Rezitis, Anthony N., and Konstantinos S. Stavropoulos. "Modeling pork supply response and price volatility: the case of Greece." Journal of Agricultural and Applied Economics 41, no. 1 (2009): 145-162

Rezitis, Anthony. "Mean and volatility spillover effects in Greek producer-consumer meat prices." Applied Economics Letters 10, no. 6 (2003): 381-384

Rydberg, Tina Hviid, and Neil Shephard. "Dynamics of trade-by-trade price movements: decomposition and models." Journal of Financial Econometrics 1, no. 1 (2003): 2-25

Hajkowicz, Stefan, Christine Negra, Paul Barnett, Megan Clark, Bronwyn Harch, and Brian Keating. "Food price volatility and hunger alleviation-can Cannes work?." Agriculture \& Food Security 1, no. 1 (2012): 8

Cox, David Roxbee, David V. Hinkley, and Ole E. Barndorff-Nielsen, eds. Time Series Models: In econometrics, finance and other fields. Vol. 65. CRC Press, 1996.

Oyejide, T. Ademola. The effects of trade and exchange rate policies on agriculture in Nigeria. Vol. 55 . Intl Food Policy Res Inst, 1986.

Salisu, Afees A., and Ismail O. Fasanya. "Modelling oil price volatility with structural breaks." Energy Policy 52 (2013): $554^{-}{ }^{-562}$

Salisu, AfeesA., and Tirimisiyu F. Oloko. "Modeling oil price-US stock nexus: AVARMA-BEKKAGARCH approach." Energy Economics 50 (2015): 1-12

Serra, Teresa, and David Zilberman. "Biofuel-related price transmission literature: A review." Energy Economics 37 (2013): 14,1-151

Tsay, Ruey S. Analysis of financial time series. Vol. 543. John Wiley \& Sons, 2005. 
Vaughan, Ignatius Olusoji, Carolyn Afolake Afolami, Tolulope Olayemi Oyekale, and Adedayo Oladipo Ayegbokiki. "An analysis of Nigeria food imports and bills." Int. J. Econ. Commerce Manage2 (2014): 1-14

Yu, Tun-Hsiang, David A. Bessler, and Stephen Fuller. "Cointegration and causality analysis of world vegetable oil and crude oil prices." In The American Agricultural Economics Association Annual Meeting, Long Beach, California, pp. 23-26. 2006.

Zheng, Yuqing, Henry W. Kinnucan, and Henry Thompson. "News and volatility of food prices." Applied Economics 4., no. 13 (2008): 1629-1635

Poterba, James M., and Lawrence H. Summers. "The persistence of volatility and stock market fluctuations." (1984).

Pinstrup-Andersen, Per, ed. Food price policy in an era of market instability: a political economy analysis. Wider Studies in Development E, 2015.

Ferrara, Laurent, Ignacio Hernando, and Daniela Marconi. International Macroeconomics in the Wake of the Global Financial Crisis. Springer, 2018.

Wilson, Izekor S. "The Causes of Poverty in the Sub-Saharan African States: A Multidimensional and Pragmatic Analysis." 
APPENDIX I. OUTPUT OF EGARCH MODEL

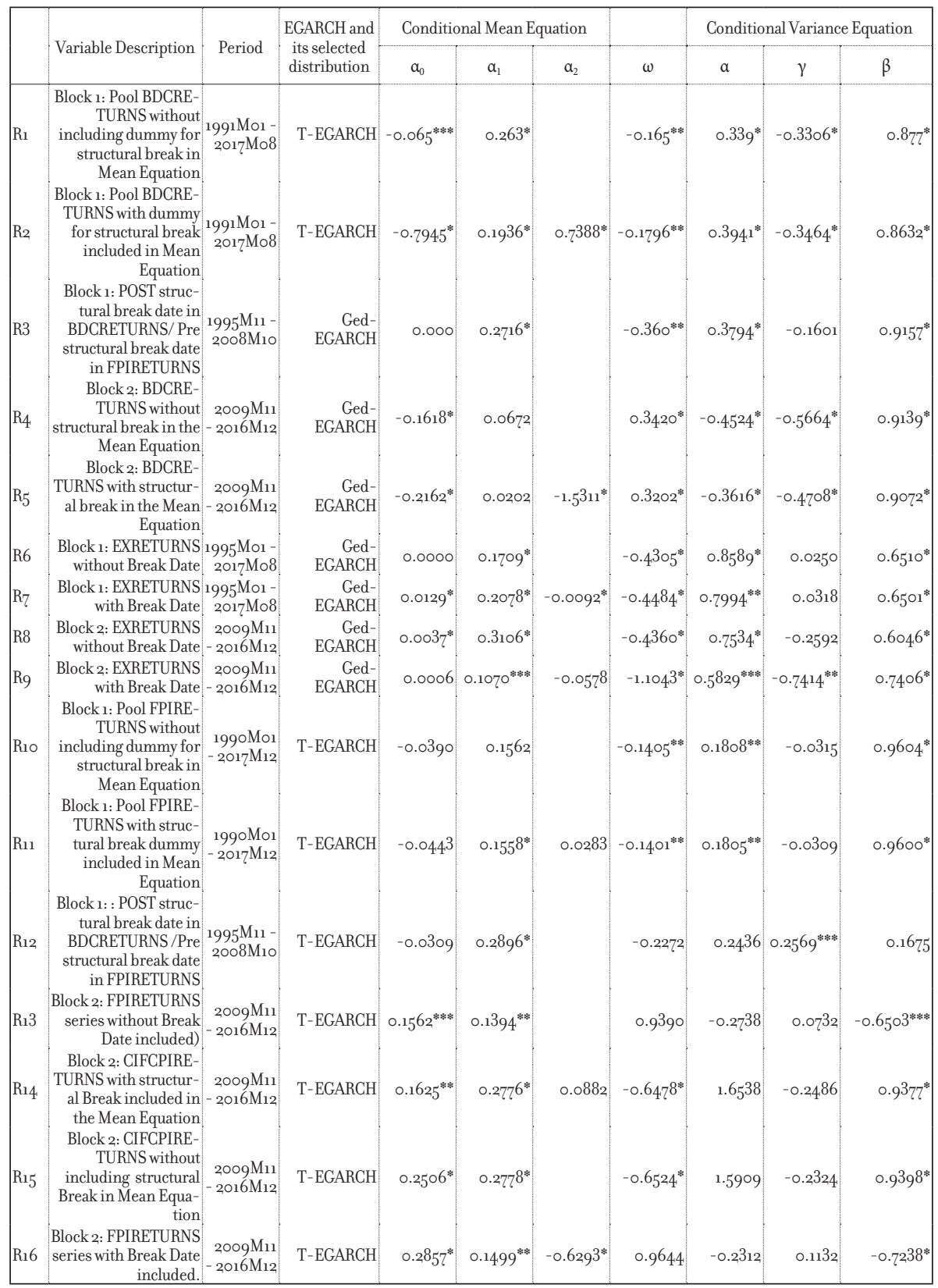

Note: $*{ }^{* *}, * * *$ mean $1 \%, 5 \%$ and $10 \%$ leel of statistical significance respectively.

Source: Data Analysis, 2018. 


\section{APPENDIX II. OUTPUT OF EXCHANGE RATE (FOREX) VOLATILITY SPILLOVER TO FOOD PRICE VOLATILITY}

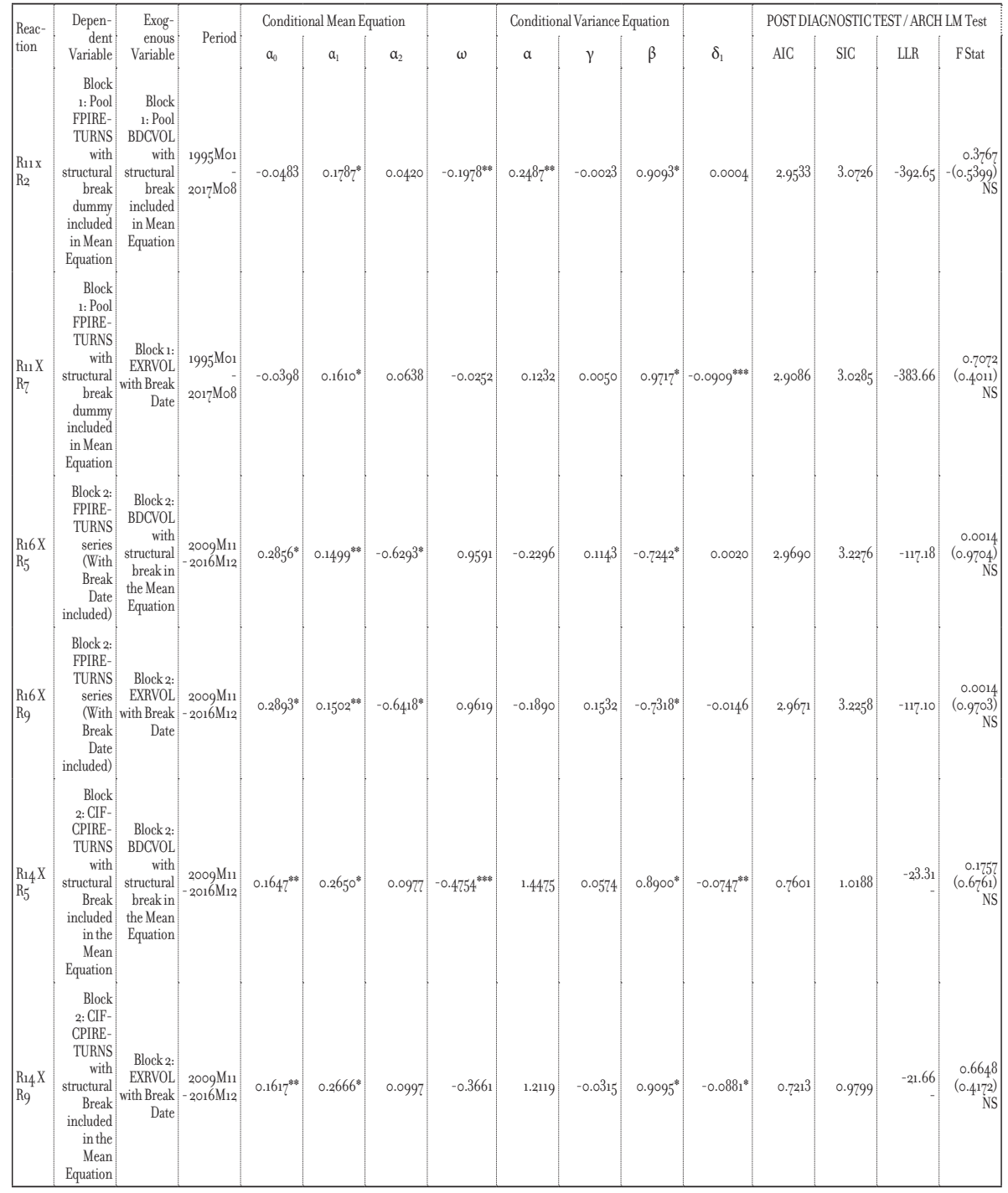

Note: ${ }^{*},{ }^{* *},{ }^{* * *}$ mean $1 \%, 5 \%$ and $10 \%$ leel of statistical significance respectively.

Source: Data Analysis, 2018. 